Revta brasil. Bot., São Paulo, V.24, n.1, p.25-34, mar. 2001

\title{
In vitro culture of Phyllanthus stipulatus (Euphorbiaceae)
}

\author{
ELIZABETE CATAPAN $^{1}$, MICHEL FLEITH OTUKI $^{1}$ and ANA MARIA VIANA ${ }^{1,2}$
}

(received: March 1, 2000; accepted: September 26, 2000)

\begin{abstract}
In vitro culture of Phyllanthus stipulatus (Euphorbiaceae)). An efficient micropropagation protocol was developed for the medicinal plant Phyllanthus stipulatus (Euphorbiaceae) using nodal segments for axillary shoot proliferation. Maximum multiplication rates (8-9 shoots per explant) was achieved on MS media supplemented with either 2.5-5.0 $\mu \mathrm{M}$ IBA. The best basal media for axillary shoot proliferation when $0.62 \mu \mathrm{M}$ BA was supplemented were MS, MS/2 and AR (4-5 shoots per explant). Rooting was achieved with $100 \%$ of the microshoots on MS medium without growth regulators. Regenerated plants were successfully acclimatized and about $88 \%$ of plantlets survived under ex vitro conditions. Flowering was observed in $81 \%$ of the ex vitro grown plantlets after 12 weeks of acclimatization. High frequency callus initiation and growth was achieved when nodal segment explants were inoculated either in the vertical position, in the light on MS medium supplemented with 5.0 $\mu \mathrm{M} \mathrm{NAA}$ or horizontally oriented, in the dark on MS supplemented with 5.0 $\mu \mathrm{M}$ NAA or 1.25-5.0 $\mu \mathrm{M}$ BA or $2 \mathrm{iP}$. Root cultures were successfully established on MS medium containing 1.1 $\mu \mathrm{M}$ NAA. The optimized micropropagation, callus and root culture protocols offer the possibility to use cell/organ culture techniques for vegetative propagation and secondary metabolism studies.
\end{abstract}

RESUMO - (Cultura in vitro de Phyllanthus stipulatus (Euphorbiaceae)). Um eficiente protocolo de micropropagação foi desenvolvido para a espécie medicinal Phyllanthus stipulatus (Euphorbiaceae) através da utilização de segmentos nodais para a proliferação de ramos. Taxas máximas de multiplicação (8-9 ramos por explante) foram obtidas em meio MS suplementado com 2,5-5,0 $\mu \mathrm{M}$ de IBA. As melhores formulações de meios de cultura quando $0,62 \mu \mathrm{M}$ de BA foi suplementado foram MS, MS/2 e AR (4-5 ramos por explante). O enraizamento foi obtido em $100 \%$ das microestacas em meio MS sem reguladores de crescimento. As microplantas regeneradas foram aclimatadas com successo e ao redor de $88 \%$ delas sobreviveram às condições ex vitro. A floração foi observada em $81 \%$ das microplantas crescidas ex vitro 12 semanas após a aclimatação. Altas freqüências de iniciação e crescimento de calos foram obtidas quando os segmentos nodais foram inoculados na posição vertical, na luz, no meio MS suplementado com 5,0 $\mu \mathrm{M}$ NAA ou na posição horizontal, no escuro em meio MS suplementado com 5,0 $\mu \mathrm{M} \mathrm{NAA}$ or 1,25-5,0 $\mu \mathrm{M}$ de BA ou 2iP. Culturas de raízes foram estabelecidas em meio MS suplementado com 1,1 $\mu \mathrm{M}$ NAA. Os protocolos otimizados de micropropagação, cultura de calos e de raízes possibilitam a utilização das técnicas de cultura de células/órgãos para a propagação vegetativa e estudos sobre o metabolismo secundário.

Key words - Shoot culture, acclimatization, ex-vitro flowering, callus culture, root culture

\section{Introduction}

The genus Phyllanthus (Euphorbiaceae) has between 550 to 750 species and several of them produce useful secondary metabolites which have been extracted from whole plants (Unander 1996). In Brazil, infusion of leaves, stems and roots of Phyllanthus spp are used in folk medicine for treating intestinal infections, diabetes, the hepatitis B virus and disturbances of the kidney and urinary bladder (Calixto $e t$ al. 1998). Several compounds such as alkaloids, tannins, flavonoids, lignans, phenols and terpenes have been isolated and identified in various species of Phyllanthus and have shown antinociceptive ac-

1. Universidade Federal de Santa Catarina, Depto de Botânica, Campus Universitário, 88040-900 Florianópolis, SC, Brasil.

2. Autor para correspondência: amarna@ @loripa.com.br tion in mice and other therapeutic activities (Cechinel Filho et al. 1996). Antiviral effects against hepatitis B virus and possibly against the reverse transcriptase of retroviruses have also been reported (Venkateswaran et al. 1987, Thyagarajan et al. 1988, Shead et al. 1992). The few studies available on the tissue culture of Phyllanthus spp. are on callus cultures of $P$. emblica, $P$. urinaria, $P$. amarus, $P$. abnormis, $P$. caroliniensis, $P$. tenellus, and $P$. niruri and on transformed root cultures of $P$. niruri (Khanna \& Nag 1973, Unander 1991, Ishimaru et al. 1992, Santos et al. 1994). Pharmacological studies carried out with callus extracts of $P$. niruri, $P$. tenellus and $P$. urinaria have shown antinociceptive properties and the main compounds identified in the extracts were flavonoids, tannins and phenols (Santos et al. 1994). Additional studies on callus and root extracts of these different species have shown the presence of phyllemblin, a tannin which has antimicrobial activity, of possible hydrolyzable tannins 
which inhibited DNA polymerase and reverse transcriptase, of geraniin and its derivatives which showed high activity in the inhibitions of HIV reverse transcriptase and angiotensin-converting enzyme involved in diabetic complications (Ueno et al. 1988, Ogata et al. 1992, Unander 1996).

P. stipulatus (Raf.) Webster is widely distributed in the Atlantic forest (Smith et al. 1988, Ulyssea \& Amaral 1997) and has not been studied yet concerning its in vitro culture potential. Therefore, the aim of the current work was to establish consistent micropropagation, callus and root culture systems for $P$. stipulatus for large scale multiplication of selected genotypes and to explore their potential for secondary metabolite studies.

\section{Material and methods}

Seeds were surface sterilized in commercial sodium hypoclorite solution (2.5\% active chlorine) with 2-3 drops of Tween 20 for $30 \mathrm{~min}$ and then rinsed three times for $10 \mathrm{~min}$ in sterile distilled water. Seeds were cultured on Murashige \& Skoog salt medium (MS, Sigma Co., USA) (Murashige \& Skoog 1962), supplemented with $2 \%(\mathrm{w} / \mathrm{v})$ sucrose and $0.2 \%$ (w/v) Phytagel (Phytagel, Sigma Co., USA). They were placed at $25{ }^{\circ} \mathrm{C}$ under $16 \mathrm{~h}$ photoperiod and photon flux of $22.3 \mu \mathrm{mol} . \mathrm{m}^{-2} . \mathrm{s}^{-1}$ at plant level, supplied by Philips TDL fluorescent light tubes. These culture conditions were used in all the experiments mentioned bellow unless otherwise stated.

Single node cuttings $(0.8-1.2 \mathrm{~cm})$, to establish shoot and callus cultures, and apical root segments $(3-4 \mathrm{~cm})$, to initiate root culture were obtained from 30-40 day old plantlets asseptically grown in the light. In experiments to test the separate effects of growth regulators on shoot and callus initiation, 6-benzyladenine (BA), kinetin, 6-( $\gamma, \gamma$-dimethylallylamino)-purine (2iP), indole-3acetic acid (IAA), indole-3-butyric acid (IBA), -naphthalene acetic acid (NAA) or 2,4-diclorophenoxyacetic acid (2,4-D) were added at either $0,0.31,0.62,1.25,2.5$ or $5.0 \mu \mathrm{M}$ to MS medium supplemented with $2 \%(\mathrm{w} / \mathrm{v})$ sucrose and $6 \%(\mathrm{w} / \mathrm{v})$ agar (Agar Type, Sigma Co.). In evaluations on the abilities of different basal media to support shoot culture establishment, MS (total and half strength), B5 (Gamborg et al. 1968), AR (Anderson 1978), W (White 1963), SH (Schenk \& Hildebrandt 1972), KM (Kao \& Michayluk 1975) and WPM (Lloyd \& McCown 1981) salts were supplemented with $0.62 \mu \mathrm{M}$ BA. For root culture initiation, root segments were inoculated in $125 \mathrm{~mL}$ erlenmeyer flasks containing $20 \mathrm{~mL}$ of MS liquid medium supplemented with $2 \%$ (w/v) sucrose, $1.1 \mu \mathrm{M}$ NAA and the cultures maintained on a rotatory shaker at $100 \mathrm{rpm}$. In all cases, the $\mathrm{pH}$ values were adjusted to 5.8 before autoclaving at $121{ }^{\circ} \mathrm{C}$ for $18 \mathrm{~min}$.

The experiments to induce shoot culture and rooting were incubated under light and those to test the effects of auxins on callus and root culture initiation were kept in the dark. In the experiments to induce shoot cultures (experiments in tables 1-4) the explants were oriented in the vertical position in the culture media while in the experiments to induce callus culture (experiments in table 6) they were oriented in the horizontal position on the surface of the media. There were 10-30 replicates per treatment in the experiments with shoot culture and callus culture and each experiment was repeated twice. Data of frequency of morphogenic responses, such as shoot, roots, flowers and/or callus formation, of fresh mass of the cultures, number of shoots and roots initiated per explant, mean shoot length and callus fresh mass were recorded after 50 days. The analysis of rooting of microcuttings excised from 50 days old plantlets, produced in MS medium or in MS supplemented with cytokinins, occurred in medium deprived of growth regulators. This experiment was performed during 40 days and in four day intervals the cultures were assessed for the frequency of rooting and the number of roots formed per explant. There were three replicates of 15 microcuttings each and the experiment was reapeated twice. For the experiments on acclimatization, 15 day old plants rooted on MS medium, having twothree roots $2.5-3.0 \mathrm{~cm}$ long were removed from the test tubes, washed free of agar; the main shoot was trimmed in such a way that two axillary buds were left per plant. The plantlets were then transferred to seed trays containing steam-sterilized medium grade river sand covered with a PVC film, for assessment during nine weeks of survival, flowering and growth. After the first week the PVC film was gradually removed and the microplants were exposed to $70 \% \mathrm{RH}$ and after 20 days they were transferred to 250 $\mathrm{mL}$ plastic pots containing a 1:1 mixture of sand and soil. At all stages of acclimatization the plantlets were kept under identical culture conditions to those used for the tissue culture studies. Three replicates having 15 microplants each were used per treatment. The root culture fresh mass in liquid media was assessed 45 days after culture, there were three replicates per treatment and the experiment repeated twice. Each set of data for plant growth regulators and basal media were analysed using ANOVA and the Least Significant Difference (LSD) test at the $95 \%$ probability level.

\section{Results and Discussion}

Axillary shoot induction, multiplication and rooting - The effects of cytokinins and auxins on morphogenesis of nodal segment explants are presented in tables 1,2 and 3. Callus initiation was stimulated at the basis of the explants in $100 \%$ of the cultures by $0.31-2.5 \mu \mathrm{M}$ BA, 1.25-5.0 $\mu \mathrm{M}$ Kinetin, 0.31$2.5 \mu \mathrm{M} 2 \mathrm{iP}$, and $1.25-5.0 \mu \mathrm{M}$ either 2,4-D or NAA. The average fresh mass of calluses produced under these latter conditions was significantly promoted by increased concentrations, and NAA at $5.0 \mu \mathrm{M}$ supported the highest callus fresh mass per explant, $c a$. $628 \mathrm{mg}$. This auxin stimulated an intensive process of root induction and growth on callus surface specially at $1.25 \mu \mathrm{M}$. Shoots were produced in $90-100 \%$ of the cultures by all growth regulators tested except 2,4-D and 2.5-5.0 $\mu \mathrm{M}$ NAA while rhizogenesis in the explants was significantly inhibited at 1.25 - 
Table 1. The frequency (\%) of morphogenic responses and callus fresh mass of nodal segment explants of Phyllanthus stipulatus after 50 days on medium containing cytokinins.

\begin{tabular}{|c|c|c|c|c|c|c|}
\hline $\begin{array}{l}\text { Growth } \\
\text { regulators }\end{array}$ & $\begin{array}{c}\text { Concentration } \\
(\mu \mathrm{M})\end{array}$ & $\begin{array}{l}\text { Shoots } \\
(\%)\end{array}$ & $\begin{array}{l}\text { Roots } \\
(\%)\end{array}$ & $\begin{array}{l}\text { Callus } \\
(\%)\end{array}$ & Normal plantlets & $\begin{array}{l}\text { Callus fresh mas } \\
\qquad(\mathrm{mg})\end{array}$ \\
\hline \multirow[t]{6}{*}{$\mathrm{BA}$} & 0.00 & ${ }^{\mathrm{y}} 100$ & ${ }^{y_{1}} 100$ & ${ }^{y_{0}}$ & $\mathrm{y}_{100}$ & $*$ \\
\hline & 0.31 & 100 & 100 & 100 & 0 & ${ }^{\mathrm{z}} 66.50 \mathrm{a}$ \\
\hline & 0.62 & 100 & 79 & 100 & 0 & $110.95 \mathrm{~b}$ \\
\hline & 1.25 & 100 & 5 & 100 & 5 & $370.55 \mathrm{~d}$ \\
\hline & 2.50 & 100 & 0 & 100 & 0 & $279.53 \mathrm{c}$ \\
\hline & 5.00 & 100 & 0 & 0 & 0 & $*$ \\
\hline \multirow[t]{6}{*}{ Kinetin } & 0.00 & 100 & 100 & 0 & 100 & $*$ \\
\hline & 0.31 & 100 & 100 & 0 & 100 & $*$ \\
\hline & 0.62 & 100 & 100 & 0 & 100 & $*$ \\
\hline & 1.25 & 100 & 100 & 100 & 0 & 86.59 a \\
\hline & 2.50 & 100 & 95 & 100 & 0 & $65.00 \mathrm{a}$ \\
\hline & 5.00 & 100 & 86 & 100 & 0 & $93.09 \mathrm{a}$ \\
\hline \multirow[t]{6}{*}{$2 \mathrm{iP}$} & 0.00 & 100 & 100 & 0 & 100 & $*$ \\
\hline & 0.31 & 100 & 96 & 100 & 0 & $74.04 \mathrm{a}$ \\
\hline & 0.62 & 100 & 100 & 100 & 0 & $105.37 \mathrm{~b}$ \\
\hline & 1.25 & 100 & 22 & 100 & 0 & $77.43 \mathrm{a}$ \\
\hline & 2.50 & 100 & 18 & 100 & 0 & $139.54 \mathrm{~b}$ \\
\hline & 5.00 & 100 & 0 & 95 & 0 & $157.23 \mathrm{~b}$ \\
\hline
\end{tabular}

${ }^{\mathrm{y}}$ Values shown were proportions obtained from 13-23 cultures.

${ }^{z}$ Values $(\mathrm{N}=13-23)$ followed by the same letters are not significant according to the LSD at the 5\% level. Letters compare concentrations.

*Treatments which did not form callus.

$5.0 \mu \mathrm{M}$ by either BA, 2iP, 2,4-D or NAA. $100 \%$ of the cultures grown on $0.31-0.62 \mu \mathrm{M}$ kinetin and at all concentrations of either IBA or IAA produced rooted plantlets, including the controls.

The effects of cytokinins and auxins at various concentrations on axillary shoot induction from nodal explants are presented in tables 2 and 4, respectively. Cytokinins did not promote intensive shoot multiplication and either had no effect or inhibited significantly the number of nodes, shoot length and culture fresh mass in comparison to the controls (table 2). The number of shoots formed per explant was maximum 1.8 when the medium had $0.62-1.25 \mu \mathrm{M}$ BA. However maximum shoot length $(c a .13 .39 \mathrm{~cm})$ and number of nodes $(c a .6 .54)$ were observed in the controls. The number of roots produced per explant was significantly reduced by BA, kinetin and 2iP. Root elongation was either not affected by BA and kinetin or was significantly inhibited by $1.25-2.5 \mu \mathrm{M} 2 \mathrm{iP}$. The auxin IBA at 2.5-5.0 $\mu \mathrm{M}$ in constrast to NAA and IAA promoted significantly culture fresh mass, shoot length (ca. 15-16.0 $\mathrm{cm}$ ) and the number of shoots and nodes produced per explant, $c a$. 2.22-2.47 and 8.78-9.83 respectively (table 4). However, similarly to IAA, IBA had no effect on either the number of roots or root length formed per explant. Of the auxins tested, only 1.25$2.5 \mu \mathrm{M}$ NAA induced a profusion of roots not in the explants itself but on the calluses induced, which shows that this auxin would be suitable for the initiation of root culture systems for futher studies on secondary metabolites as already established for $P$. niruri (Ishimaru et al. 1992). 
Table 2. Effect of cytokinins on shoot culture initiation from nodal segment explants of Phyllanthus stipulatus after 50 days.

\begin{tabular}{|c|c|c|c|c|c|c|c|}
\hline $\begin{array}{l}\text { Growth } \\
\text { regulators }\end{array}$ & $\begin{array}{c}\text { Concentration } \\
(\mu \mathrm{M})\end{array}$ & $\begin{array}{l}\text { Culture fresh } \\
\text { mass (mg) }\end{array}$ & $\begin{array}{c}\text { No. of } \\
\text { shoots/explant }\end{array}$ & $\begin{array}{l}\text { Shoot length } \\
(\mathrm{cm})\end{array}$ & $\begin{array}{c}\text { No. of } \\
\text { nodes/explant }\end{array}$ & $\begin{array}{l}\text { Root length } \\
(\mathrm{cm})\end{array}$ & $\begin{array}{l}\text { No. of } \\
\text { roots/explant }\end{array}$ \\
\hline \multirow[t]{6}{*}{$\mathrm{BA}$} & 0.00 & ${ }^{z} 247.45 \mathrm{c}$ & $1.08 \mathrm{a}$ & $13.39 \mathrm{~d}$ & $6.54 \mathrm{a}$ & $2.31 \mathrm{a}$ & $11.83 \mathrm{~b}$ \\
\hline & 0.31 & $78.79 \mathrm{~b}$ & $1.50 \mathrm{~b}$ & $8.29 \mathrm{c}$ & $5.08 \mathrm{a}$ & $2.16 \mathrm{a}$ & $5.70 \mathrm{a}$ \\
\hline & 0.62 & $70.66 \mathrm{~b}$ & $1.83 \mathrm{c}$ & $7.83 \mathrm{c}$ & $5.08 \mathrm{a}$ & $2.05 \mathrm{a}$ & $2.05 \mathrm{a}$ \\
\hline & 1.25 & $37.26 \mathrm{a}$ & $1.84 \mathrm{c}$ & $3.39 \mathrm{~b}$ & $5.63 \mathrm{a}$ & $*$ & $*$ \\
\hline & 2.50 & $27.80 \mathrm{a}$ & $1.73 \mathrm{~b}$ & $1.86 \mathrm{a}$ & $5.73 \mathrm{a}$ & $*$ & $*$ \\
\hline & 5.00 & $54.53 \mathrm{~b}$ & $1.61 \mathrm{~b}$ & $1.53 \mathrm{a}$ & $5.23 \mathrm{a}$ & $*$ & $*$ \\
\hline \multirow[t]{6}{*}{ Kinetin } & 0.00 & $247.45 \mathrm{c}$ & $1.08 \mathrm{a}$ & $13.39 \mathrm{c}$ & $6.54 \mathrm{c}$ & $2.31 \mathrm{a}$ & $11.83 \mathrm{~d}$ \\
\hline & 0.31 & $218.18 \mathrm{c}$ & $1.12 \mathrm{a}$ & $11.90 \mathrm{~b}$ & $4.45 \mathrm{~b}$ & $2.02 \mathrm{a}$ & $10.66 \mathrm{~d}$ \\
\hline & 0.62 & $175.5 \mathrm{~b}$ & $1.54 \mathrm{~b}$ & $11.85 \mathrm{~b}$ & $5.33 \mathrm{~b}$ & $2.31 \mathrm{a}$ & $9.59 \mathrm{c}$ \\
\hline & 1.25 & $73.32 \mathrm{a}$ & $1.22 \mathrm{a}$ & $9.36 \mathrm{a}$ & $4.18 \mathrm{~b}$ & $2.40 \mathrm{a}$ & $6.22 \mathrm{~b}$ \\
\hline & 2.50 & $52.54 \mathrm{a}$ & $1.13 \mathrm{a}$ & $6.79 \mathrm{a}$ & $3.36 \mathrm{a}$ & $1.76 \mathrm{a}$ & $4.47 \mathrm{a}$ \\
\hline & 5.00 & $57.59 \mathrm{a}$ & $1.31 \mathrm{a}$ & $7.22 \mathrm{a}$ & $3.40 \mathrm{a}$ & $2.21 \mathrm{a}$ & $3.68 \mathrm{a}$ \\
\hline \multirow[t]{6}{*}{$2 \mathrm{iP}$} & 0.00 & $247.45 \mathrm{c}$ & $1.08 \mathrm{a}$ & $13.39 \mathrm{c}$ & $6.54 \mathrm{c}$ & $2.31 \mathrm{~b}$ & $11.83 \mathrm{c}$ \\
\hline & 0.31 & $79.37 \mathrm{~b}$ & $1.12 \mathrm{a}$ & $10.08 \mathrm{~b}$ & $3.95 \mathrm{a}$ & $2.04 \mathrm{~b}$ & $2.95 \mathrm{~b}$ \\
\hline & 0.62 & $67.04 \mathrm{~b}$ & $1.29 \mathrm{a}$ & $9.43 \mathrm{~b}$ & $3.37 \mathrm{a}$ & $2.00 \mathrm{~b}$ & $3.50 \mathrm{~b}$ \\
\hline & 1.25 & $33.82 \mathrm{a}$ & $1.08 \mathrm{a}$ & $5.76 \mathrm{~b}$ & $3.52 \mathrm{a}$ & $0.46 \mathrm{a}$ & $1.20 \mathrm{a}$ \\
\hline & 2.50 & $34.13 \mathrm{a}$ & $1.41 \mathrm{a}$ & $5.02 \mathrm{~b}$ & $4.04 \mathrm{~b}$ & $0.87 \mathrm{a}$ & $1.50 \mathrm{a}$ \\
\hline & 5.00 & $22.68 \mathrm{a}$ & $1.50 \mathrm{~b}$ & $3.02 \mathrm{a}$ & $5.22 \mathrm{c}$ & $*$ & $*$ \\
\hline
\end{tabular}

${ }^{z}$ Values $(N=24-30)$ followed by the same letters are not significant according to the LSD at the 5\% level. Letters compare concentrations. *Treatments which did not form roots.

These are the first attempts to establish shoot cultures of this species and the results obtained show that the unusual promotive effects of IBA on shoot culture growth was not only due to the increase in axillary shoot proliferation but also in the number of axillary buds formed in the shoots which can be used as starting plant material for further multiplication. Similar results were obtained for Dioscorea composita shoot cultures, where NAA, IAA and IBA stimulated significantly the number of nodes per plantlet in comparison to cytokinins (Alizadeh et al. 1998). However, for other Phyllanthus species, such as $P$. tenellus, $P$. niruri, $P$. caroliniensis, $P$. urinaria and $P$. fraternus (Catapan 1999, Saradhi \& Islamia 1997) and for other Euphorbiaceae species, such as Excoecaria agallocha L. (Rao et al. 1998) cytokinins stimulated shoot proliferation. Root initiation usually is promoted by exogenous auxins (McCown 1988, Drew et al. 1991) and inhibited by exogenous cytokinins (Pierik 1989, De Klerk et al. 1995). In this report root initiation in the explant was inhibited by cytokinins only at concentrations higher than $1.25 \mu \mathrm{M}$ BA and similar results on the inhibition of root primordia differentiation by BA are reported for sunflower (Fabijan et al. 1981). Auxins like IBA and IAA did not have stimulatory effect in terms of promoting root proliferation and elongation as expected.

Data shown in table 5 indicate that some tissue culture media supplemented with $0.62 \mu \mathrm{M}$ BA had variable effects on growth of uninodal explants. Although shoot initiation was observed in $70-100 \%$ of the cultures, rhizogenesis was completely inhibited at all salt formulations tested except on MS, MS/2 and WPM. Callus initiation was observed only on MS and MS/2. MS/2 supported the maximum number of shoots (ca. 3.40) and shoot elongation (ca. 
Table 3. The frequency (\%) of morphogenic responses and callus fresh mass of nodal segment explants of Phyllanthus stipulatus after 50 days on medium containing auxins.

\begin{tabular}{|c|c|c|c|c|c|c|c|}
\hline $\begin{array}{l}\text { Growth } \\
\text { regulators }\end{array}$ & $\begin{array}{c}\text { Concentration } \\
(\mu \mathrm{M})\end{array}$ & $\begin{array}{c}\text { Shoots } \\
(\%)\end{array}$ & $\begin{array}{l}\text { Roots } \\
(\%)\end{array}$ & $\begin{array}{c}\text { Callus } \\
(\%)\end{array}$ & $\begin{array}{l}\text { Normal } \\
\text { plantlets }\end{array}$ & $\begin{array}{l}\text { Callus fresh } \\
\text { mass (mg) }\end{array}$ & $\begin{array}{l}\text { Root fresh } \\
\text { mass (mg) }\end{array}$ \\
\hline \multirow[t]{4}{*}{ 2,4-D } & 0.00 & 100 & 100 & 0 & 100 & $*$ & $*$ \\
\hline & 1.25 & 0 & 0 & 100 & 0 & ${ }^{\mathrm{z}} 209.75 \mathrm{a}$ & $*$ \\
\hline & 2.50 & 0 & 0 & 100 & 0 & $296.85 \mathrm{~b}$ & $*$ \\
\hline & 5.00 & 0 & 0 & 100 & 0 & $373.15 \mathrm{c}$ & $*$ \\
\hline \multirow[t]{4}{*}{ IBA } & 0.00 & 100 & 100 & 0 & 100 & $*$ & * \\
\hline & 1.25 & 100 & 100 & 0 & 100 & $*$ & $*$ \\
\hline & 2.50 & 100 & 100 & 0 & 100 & $*$ & $*$ \\
\hline & 5.00 & 100 & 100 & 0 & 100 & $*$ & $*$ \\
\hline \multirow[t]{4}{*}{ NAA } & 0.00 & 100 & 100 & 0 & 100 & $*$ & $*$ \\
\hline & 1.25 & 90 & 0 & 100 & 0 & $203.95 \mathrm{a}$ & ${ }^{\mathrm{z}} 178.80 \mathrm{~b}$ \\
\hline & 2.50 & 45 & 0 & 100 & 0 & $400.50 \mathrm{~b}$ & $127.05 \mathrm{ab}$ \\
\hline & 5.00 & 0 & 0 & 100 & 0 & $628.00 \mathrm{c}$ & 86.52 a \\
\hline \multirow[t]{4}{*}{ IAA } & 0.00 & 100 & 100 & 0 & 100 & $*$ & $*$ \\
\hline & 1.25 & 100 & 100 & 0 & 100 & $*$ & $*$ \\
\hline & 2.50 & 100 & 100 & 0 & 100 & $*$ & $*$ \\
\hline & 5.00 & 100 & 100 & 0 & 100 & $*$ & $*$ \\
\hline
\end{tabular}

${ }^{\mathrm{y}}$ Values shown were proportions obtained from 30 cultures.

${ }^{z}$ Values $(\mathrm{N}=12-20)$ followed by the same letters are not significant according to the LSD at the 5\% level. Letters compare concentrations. *Treatments which did not form callus or roots.

$6.75 \mathrm{~cm})$ per explant while AR supported the maximum number of nodes (ca. 5.70). Similar results in terms of number of shoots, number of nodes and shoot length were observed on MS and WPM. These differences and similarities might be due to their basal salt formulation: the ammonium:nitrate rates are $0.52 \mathrm{mM}$, for $\mathrm{MS}, 0.727 \mathrm{mM}$, for $\mathrm{AR}$ and 0.51 for WPM and the total ionic strength are $94.25 \mathrm{mM}$, $86.48 \mathrm{mM}$ and $42.39 \mathrm{mM}$, respectively (McCown \& Sellmer 1987). Interestingly the reduction in the salt strength of MS media to 50\% did not reduce shoot culture growth as observed for $P$. caroliniensis (Catapan 1999). The poorest shoot growth of the cultures in terms of number of shoots and nodes was observed on $\mathrm{B} 5, \mathrm{SH}, \mathrm{W}$ and $\mathrm{KM}$ and in terms of shoot elongation on $\mathrm{B} 5$ and $\mathrm{W}$. This is probably due to their low ammonium content compared to MS.
Root initiation on microcuttings excised from plantlets produced on MS without growth regulators or on MS supplemented with cytokinins and then transferred to MS medium started between zero and four days after culture, reaching $100 \%$ of the cultures after 16 days. Approximately the same length of time was required for other species such as $P$. urinaria and $P$. fraternus to achieve maximum in vitro rooting rates, however for $P$. caroliniensis 48 days were necessary (Catapan 1999). The maximum number of roots per explant observed under this culture condition was $c a$. 6.66. In the controls (tables 2 and 4) the average number of roots produced per explant after 50 days varied from 7.73-11.83 and root length varied from $2.31-3.65 \mathrm{~cm}$. The spontaneous rooting observed in the explants cultured on media without any growth regulators is an indication that optimal endogenous levels of plant growth regulators re- 
Table 4. Effect of auxins on shoot culture initiation from nodal segment explants of Phyllanthus stipulatus after 50 days.

\begin{tabular}{|c|c|c|c|c|c|c|c|}
\hline $\begin{array}{l}\text { Growth } \\
\text { regulators }\end{array}$ & $\begin{array}{c}\text { Concentration } \\
(\mu \mathrm{M})\end{array}$ & $\begin{array}{l}\text { Culture fresh } \\
\text { mass }(\mathrm{mg})\end{array}$ & $\begin{array}{c}\text { No. of } \\
\text { shoots/explant }\end{array}$ & $\begin{array}{l}\text { Shoot length } \\
(\mathrm{cm})\end{array}$ & $\begin{array}{c}\text { No. of } \\
\text { nodes/explant }\end{array}$ & $\begin{array}{l}\text { Root length } \\
\quad(\mathrm{cm})\end{array}$ & $\begin{array}{l}\text { No. of } \\
\text { roots/explant }\end{array}$ \\
\hline \multirow[t]{4}{*}{ 2,4-D } & 0.00 & 168.63 & 1.57 & 14.65 & 7.63 & 3.65 & 7.73 \\
\hline & 1.25 & $*$ & $*$ & $*$ & $*$ & $*$ & $*$ \\
\hline & 2.50 & $*$ & $*$ & $*$ & $*$ & $*$ & $*$ \\
\hline & 5.00 & $*$ & $*$ & $*$ & $*$ & $*$ & $*$ \\
\hline \multirow[t]{4}{*}{ IBA } & 0.00 & ${ }^{z} 168.63 \mathrm{a}$ & $1.57 \mathrm{a}$ & $14.65 \mathrm{ab}$ & $7.63 \mathrm{ab}$ & $3.65 \mathrm{~b}$ & $7.73 \mathrm{a}$ \\
\hline & 1.25 & $170.64 \mathrm{a}$ & $1.52 \mathrm{a}$ & $13.23 \mathrm{a}$ & $6.64 \mathrm{a}$ & $3.41 \mathrm{ab}$ & $7.58 \mathrm{a}$ \\
\hline & 2.50 & $207.15 \mathrm{ab}$ & $2.47 \mathrm{~b}$ & $15.03 \mathrm{~b}$ & $8.78 \mathrm{ab}$ & $3.00 \mathrm{a}$ & $7.05 \mathrm{a}$ \\
\hline & 5.00 & $251.05 \mathrm{~b}$ & $2.22 \mathrm{~b}$ & $16.63 \mathrm{c}$ & $9.83 \mathrm{~b}$ & $3.19 \mathrm{ab}$ & $8.11 \mathrm{a}$ \\
\hline \multirow[t]{4}{*}{ NAA } & 0.00 & $168.63 \mathrm{a}$ & $1.57 \mathrm{a}$ & $14.65 \mathrm{~b}$ & $7.63 \mathrm{~b}$ & $3.65 \mathrm{a}$ & 7.73 \\
\hline & 1.25 & $155.27 \mathrm{a}$ & $1.55 \mathrm{a}$ & $12.05 \mathrm{a}$ & $5.88 \mathrm{a}$ & $3.77 \mathrm{a}$ & 7.73 \\
\hline & 2.50 & $112.11 \mathrm{a}$ & $1.11 \mathrm{a}$ & $11.77 \mathrm{a}$ & $4.44 \mathrm{a}$ & $3.22 \mathrm{a}$ & 7.73 \\
\hline & 5.00 & $*$ & $*$ & $*$ & $*$ & $*$ & $*$ \\
\hline \multirow[t]{4}{*}{ IAA } & 0.00 & $168.63 \mathrm{~b}$ & $1.57 \mathrm{a}$ & $14.65 \mathrm{a}$ & $7.63 \mathrm{~b}$ & $3.65 \mathrm{a}$ & $7.73 \mathrm{a}$ \\
\hline & 1.25 & $160.64 \mathrm{ab}$ & $1.52 \mathrm{a}$ & $13.91 \mathrm{a}$ & $6.23 \mathrm{a}$ & $2.50 \mathrm{a}$ & $6.47 \mathrm{a}$ \\
\hline & 2.50 & $123.83 \mathrm{a}$ & $1.41 \mathrm{a}$ & $13.50 \mathrm{a}$ & $5.50 \mathrm{a}$ & $2.48 \mathrm{a}$ & $6.16 \mathrm{a}$ \\
\hline & 5.00 & $162.91 \mathrm{ab}$ & $1.58 \mathrm{a}$ & $14.45 \mathrm{a}$ & $8.08 \mathrm{~b}$ & $2.58 \mathrm{a}$ & $7.75 \mathrm{a}$ \\
\hline
\end{tabular}

${ }^{z}$ Values $(\mathrm{N}=12-20)$ followed by the same letters are not significant according to the LSD at the $5 \%$ level. Letters compare concentrations. *Treatments which did not form microplants.

Table 5. Effect of basal media salt formulation supplemented with $0.62 \mu \mathrm{M}$ BA on the frequency (\%) of morphogenic responses and shoot initiation from nodal segment explants of Phyllanthus stipulatus after 50 days.

\begin{tabular}{lccccccc}
\hline Basal medium & Shoots $(\%)$ & $\begin{array}{c}\text { Roots } \\
(\%)\end{array}$ & $\begin{array}{c}\text { Callus } \\
(\%)\end{array}$ & $\begin{array}{c}\text { Culture fresh } \\
\text { weight }(\mathrm{mg})\end{array}$ & $\begin{array}{c}\text { No. of } \\
\text { shoots/explant }\end{array}$ & $\begin{array}{c}\text { No. of } \\
\text { nodes/explant }\end{array}$ & $\begin{array}{c}\text { Shoot length } \\
(\mathrm{cm})\end{array}$ \\
\hline MS & $\mathrm{y}^{1} 100$ & $\mathrm{y}_{90}$ & $\mathrm{y}_{90}$ & ${ }^{z} 95.70 \mathrm{c}$ & ${ }^{z} 1.40 \mathrm{ab}$ & ${ }^{2} 4.30 \mathrm{~cd}$ & ${ }^{7} 7.00 \mathrm{~d}$ \\
B5 & 90 & 0 & 0 & $51.44 \mathrm{~b}$ & $1.33 \mathrm{ab}$ & $2.77 \mathrm{~b}$ & $1.88 \mathrm{a}$ \\
SH & 70 & 0 & 0 & $83.42 \mathrm{c}$ & $1.14 \mathrm{ab}$ & $3.42 \mathrm{bc}$ & $3.92 \mathrm{~b}$ \\
W & 90 & 0 & 0 & $12.00 \mathrm{a}$ & $1.00 \mathrm{a}$ & $1.22 \mathrm{a}$ & $1.16 \mathrm{a}$ \\
KM & 100 & 0 & 0 & $51.70 \mathrm{~b}$ & $1.00 \mathrm{a}$ & $3.40 \mathrm{bc}$ & $5.35 \mathrm{c}$ \\
WPM & 90 & 50 & 0 & $71.22 \mathrm{c}$ & $1.66 \mathrm{ab}$ & $4.30 \mathrm{~cd}$ & $7.16 \mathrm{~d}$ \\
AR & 100 & 0 & 0 & $61.10 \mathrm{~b}$ & $2.30 \mathrm{~b}$ & $5.70 \mathrm{~d}$ & $3.65 \mathrm{~b}$ \\
MS/2 & 100 & 80 & 90 & $241.40 \mathrm{~d}$ & $3.40 \mathrm{c}$ & $5.30 \mathrm{~cd}$ & $6.75 \mathrm{~d}$ \\
\hline
\end{tabular}

${ }^{\mathrm{y}}$ Values shown were proportions obtained from 10 cultures.

${ }^{z}$ Values $(\mathrm{N}=10)$ within a single column followed by the same letter were not signifcantly different according to the LSD at the $5 \%$ level. 
quired for rooting are already present in the original explants.

Hardening of regenerated plants - Plantlets were successfully acclimatized without mist-house/ shade-house facilities. $100 \%$ of the plantlets survived hardening on river sand for three weeks and for another two weeks after transfer to potting medium consisting of 1:1 garden soil sand. However, the survival decreased to 94.4 and $88.8 \%$, respectively after five and eight weeks of acclimatization. The initial growth rates for height and number of shoots per plant were respectively $3.8 \pm 0.01 \mathrm{~cm}$ and $1.0 \pm 0.0$ during the first three weeks of acclimatization. However, in the following six weeks a 2.5 fold increase in height was observed contrasting to 0.36 fold increase in shoot number. Ex vitro flowering reached $81 \%$ after 12 weeks after acclimatization. These results show that a low cost system is now available for large scale multiplication of selected clones of this species.

Callus and root culture - The plant growth regulators 2,4-D, IBA, NAA, IAA, BAP and 2iP were equally effective in callus initiation (90-100\%) from single node explants inoculated horizontally on the media and maintained in the dark (table 6). Only kinetin induced lower rates $(65-80 \%)$ of callus in the explants. Rhizogenesis in the explants and in calluses was observed in $100 \%$ of the cultures on IBA, NAA and IAA. None of the cytokinins tested induced roots. These results contrast to those presented in table 3 concerning the unability of the auxins IBA and IAA on callus induction in explants in the vertical and show the strong influence of explant orientation on in vitro responses. Similarly, the rates of callus induction by BA and $2 \mathrm{iP}$ were lower than $22 \%$ at $1.25-5.0 \mu \mathrm{M}$ in explants in the vertical and reached $90-100 \%$ in explants oriented horizontally on the media surface. Although high frequencies of callus initiation were observed for all auxins tested in the dark, only $1.25 \mu \mathrm{M} 2,4-\mathrm{D}$ and $5.0 \mu \mathrm{M}$ NAA supported significant callus growth of $c a .266$ and $398 \mathrm{mg}$ average fresh mass per explant, respectively (table 6). Similar promotive effect was verified at all concentrations of $\mathrm{BA}$ and $2 \mathrm{iP}$ when calluses with 345-393 and 286-311 $\mathrm{mg}$ fresh weight respectively were obtained. No consistent effect on callus fresh mass increase was observed for IBA, IAA or kinetin ( $\leq 165 \mathrm{mg}$ per explant). Callus initiation and growth is dependent on the presence of equal auxin:cytokinin endogenous ratios, therefore the activity of cytokinins on cell division is only possible in the presence of an auxin (Krikorian 1995). The fact that cytokinins such as $\mathrm{BA}$ and $2 \mathrm{iP}$ were as effective as the auxins 2,4-D and NAA in promoting callus growth in this species is an indication that the level of uptake and metabolism of these plant growth regulators by the explants in the horizontal allows the appropriate endogenous levels of cytokinins to couterbalance the levels of endogenous auxins and vice-versa. The results of $5.0 \mu \mathrm{M}$ NAA (table 3), when calluses with average fresh mass higher than $600 \mathrm{mg}$ were obtained after the same period of time with explants oriented in the vertical position on culture media might be due to either the favourable conditions for the uptake and metabolism of this auxin, or to the possible promotive effect of light. Similar results were obtained for $P$. caroliniensis, but with 5.0 $\mu \mathrm{M}$ 2,4-D. Preliminary experiments carried out with this species have also shown significant promotive effect of light on callus fresh mass in the explants oriented horizontally (Catapan 1999). Endogenous and applied auxins can move in the plant vascular system both in the phloem and in the xylem (Lomax et al. 1995), therefore it may possibly be that higher kinetics of NAA uptake and transport to receiver cells in the stem, probably located in the vascular cambium, were facilitated when the explants were oriented in the vertical position.

The preliminary results on root culture growth showed that $c a .1250 \pm 0.33 \mathrm{mg}$ in root fresh mass increase was obtained after 45 days of culture. This value is similar to the ones observed for $P$. caroliniensis (Catapan 1999).

This is the first successful attempt to initiate and sustain callus and root growth of this species and the calluses produced by these systems have also been used in further pharmacological and phytochemical analysis by gas chromatography. These preliminary studies have shown that calluses extracts showed antinociceptive activities in different models of pain in mice and the presence of stigmasterol and the triterpene glochidonol (Catapan 1999). Neither alkaloids or phenolic compounds were detected. The possible presence of glochidone and stigmasterol in the root extracts need still to be confirmed. Glochidone and stigmasterol have been shown recently to 
Table 6. The frequency (\%) of morphogenic responses and callus fresh mass from nodal segment explants of Phyllanthus stipulatus inoculated in the horizontal position on MS medium supplemented with auxins and cytokinins.

\begin{tabular}{|c|c|c|c|c|c|}
\hline Auxins & $\begin{array}{c}\text { Concentration } \\
(\mu \mathrm{M})\end{array}$ & $\begin{array}{l}\text { Root } \\
(\%)\end{array}$ & $\begin{array}{l}\text { Callus } \\
(\%)\end{array}$ & $\begin{array}{l}\text { Callus fresh mass } \\
\qquad(\mathrm{mg})\end{array}$ & $\begin{array}{l}\text { Root fresh mass } \\
(\mathrm{mg})\end{array}$ \\
\hline \multirow[t]{4}{*}{ 2,4-D } & 0.00 & 100 & 0 & $*$ & $* *$ \\
\hline & 1.25 & 0 & 100 & ${ }^{z_{2}} 266.41 b$ & $* *$ \\
\hline & 2.50 & 0 & 100 & $252.27 \mathrm{ab}$ & $* *$ \\
\hline & 5.00 & 0 & 100 & $230.04 \mathrm{a}$ & $* *$ \\
\hline \multirow[t]{4}{*}{ IBA } & 0.00 & 100 & 0 & $*$ & $* *$ \\
\hline & 1.25 & 100 & 100 & $40.28 \mathrm{a}$ & $42.57 \mathrm{a}$ \\
\hline & 2.50 & 100 & 100 & $71.31 \mathrm{a}$ & $67.59 \mathrm{a}$ \\
\hline & 5.00 & 100 & 100 & $101.23 \mathrm{~b}$ & $103.36 \mathrm{~b}$ \\
\hline \multirow[t]{4}{*}{$\mathrm{NAA}$} & 0.00 & 100 & 0 & $*$ & $* *$ \\
\hline & 1.25 & 100 & 100 & $286.31 \mathrm{a}$ & $179.18 \mathrm{a}$ \\
\hline & 2.50 & 100 & 100 & $277.04 \mathrm{a}$ & $211.13 \mathrm{a}$ \\
\hline & 5.00 & 100 & 100 & $398.45 \mathrm{~b}$ & 185.86 a \\
\hline \multirow[t]{4}{*}{ IAA } & 0.00 & 100 & 0 & $*$ & $* *$ \\
\hline & 1.25 & 100 & 100 & $154.27 \mathrm{~b}$ & $33.59 \mathrm{a}$ \\
\hline & 2.50 & 100 & 100 & $165.80 \mathrm{~b}$ & $24.94 \mathrm{a}$ \\
\hline & 5.00 & 100 & 100 & $129.50 \mathrm{a}$ & $58.68 \mathrm{a}$ \\
\hline \multirow[t]{4}{*}{ BA } & 0.00 & 100 & 0 & $*$ & $* *$ \\
\hline & 1.25 & 0 & 90 & $345.22 \mathrm{a}$ & $* *$ \\
\hline & 2.50 & 0 & 100 & $369.42 \mathrm{a}$ & $* *$ \\
\hline & 5.00 & 0 & 95 & $393.85 \mathrm{a}$ & $* *$ \\
\hline \multirow[t]{4}{*}{ Kinetin } & 0.00 & 100 & 0 & $*$ & $* *$ \\
\hline & 1.25 & 0 & 80 & $44.62 \mathrm{a}$ & $* *$ \\
\hline & 2.50 & 0 & 80 & $77.00 \mathrm{a}$ & $* *$ \\
\hline & 5.00 & 0 & 65 & $66.76 \mathrm{a}$ & $* *$ \\
\hline \multirow[t]{4}{*}{$2 \mathrm{iP}$} & 0.00 & 100 & 0 & $*$ & $* *$ \\
\hline & 1.25 & 0 & 90 & $294.61 \mathrm{a}$ & $* *$ \\
\hline & 2.50 & 0 & 100 & $286.90 \mathrm{a}$ & $* *$ \\
\hline & 5.00 & 0 & 100 & $311.16 \mathrm{a}$ & $* *$ \\
\hline
\end{tabular}

${ }^{z}$ Values $(\mathrm{N}=30)$ followed by the same letters are not significantly different according to the LSD at the level of $5 \%$. Letters compare concentrations.

*Treatments which did not form callus.

**Treatments which did not form roots or root fresh mass $<20 \mathrm{mg}$. 
have strong activity against neurogenic and inflammatory pain (Krogh et al. 1999). Therefore, the calluses and root culture systems described in this report can now be used to foster the studies on secondary metabolism.

Acknowledgements - The authors thank the Conselho Nacional de Desenvolvimento Científico e Tecnológico (CNPq/Brasil) for the fellowship held by Elizabete Catapan and Leila da Graça Amaral for classification of plant material.

\section{References}

ALIZADEH, S.A, MANTELL, S.H. \& VIANA, A.M. 1998. In vitro shoot culture and microtuber induction in the steroid yam Dioscorea composita Hemsl. Plant Cell Tissue and Organ Culture 53:107-112.

ANDERSON, W.C. 1978. Tissue culture propagation of Rhododendrons. In Vitro 14:334.

CALIXTO, J.B., SANTOS, A.R.S., CECHINEL FILHO, V. \& YUNES, R.A. 1998. A review of the plants of the genus Phyllanthus: Their chemistry, pharmacology and therapeutic potential. Medical Research Review 4:225-258.

CATAPAN, E. 1999. Cultivo in vitro e análises fitoquímicas de espécies de Phyllanthus. Tese de Mestrado, Universidade Federal de Santa Catarina, Florianópolis.

CECHINEL FILHO, V., SANTOS, A.R.S., CAMPOS, R.O.P., MIGUEL, O.G., YUNES, R.A., FERRARI, F., MESSANA, J. \& CALIXTO, J.B. 1996. Chemical and pharmacological studies of Phyllanthus caroliniensis in mice. Journal of Pharmaceutical Pharmacology 48:1231-1236.

DE KLERK, G.J., KEPPEL, M. \& BRUGGE, J.T. 1995. Timing of the phases in adventitious root formation in apple microcuttings. Journal of Experimental Botany 46:965-972.

DREW, R.A., SIMPSON, B.W. \& OSBORNE, W.J. 1991. Degradation of exogenous indole-3-butyric acid and riboflavin and their influence of rooting response of papaya in vitro. Plant Cell Tissue and Organ Culture 26:29-34.

FABIJAN, D., TAYLOR, J.S. \& REID, D.M. 1981. Adventitious rooting in hypocotyls of sunflower (Helianthus annuиs) seedlings II. Action of gibberellins, cytokinins, auxins and ethylene. Physiologia Plantarum 53:589-597.

GAMBORG, O.L. \& EVELEIGH, D.E. 1968. Culture methods and detection of glucanases in suspension cultures of wheat and barley. Canadian Journal of Biochemistry 46:417-421.

ISHIMARU, K., YOSHIMATSU, K., YAMAKAWA, T., KAMADA, H. \& SHIMOMURA, K. 1992. Phenolic constituents in tissue cultures of Phyllanthus niruri. Phytochemistry 34:2015-2016.

KAO, K.N. \& MICHAYLUK, M.R. 1975. Nutritional requirements for growth of Vicia hajastana cells and protoplasts at a very low population density in liquid media. Planta 126:105-110.

KHANA, P. \& NAG, T.N. 1973. Isolation, identification and screening of phyllemblin from Emblica officinalis Gaertn. tissue culture. Indian Journal of Pharmacology 35:23-25.
KRIKORIAN, A.D. 1995. Hormones in tissue culture and micropropagation. In Plant hormones: physiology, biochemistry and molecular biology (P.J. Davies, ed.). Kluwer Academic Publishers, Dordrecht, p.774-796.

KROGH, R., KROTH, R., BERTI, C., MADEIRA, A.O., SOUZA, M.M., CECHINEL FILHO, V., DELLE-MONACHE, F. \& YUNES, R.A. 1999. Isolation and identification of compounds with antinociceptive action from Ipomoea pes-capre (L.) R.Br. Pharmazie 54:1-6.

LOMAX, T.L., MUDAY, G.K. \& RUBERY, P.H. 1995. Auxin transport. In Plant hormones: physiology, biochemistry and molecular biology (P.J. Davies, ed.). Kluwer Academic Publishers, Dordrecht, p.509-530.

LLOYD, G. \& MCCOWN, B. 1981. Commercially feasible micropropagation of mountain laurel, Kalmia latifolia, by use of shoot tip culture. International Plant Propagation Society Proceedings 30:421-427.

MCCOWN, B.H. 1988. Adventitious rooting of tissue cultured plants. In Adventitious root formation in cuttings (T.D. Davis, B.E. Hassig \& N. Shankhla, eds.). Dioscorides Press, Portland, p.289-302.

MCCOWN, B.H. \& SELLMER, J.C. 1987. General media and vessels suitable for woody plant culture. In Cell and tissue culture in forestry (J.M. Bonga and D.J. Durzan, eds.), v.1, General Principles and Biotechnology. Martinus Nijhoff Publishers, Dordrecht, p.4-16.

MURASHIGE, T. \& SKOOG, F. 1962. A revised medium for rapid growth and bioassays with tobacco tissue cultures. Physiologia Plantarum 15:473-497.

OGATA, T., HIGUCHI, H., MOCHIDA, S., MATSUMOTO, H., KATO, A., ENDO, T., KAJI, A. \& KAJI, H. 1992. HIV-1 reverse transcriptase inhibitor from Phyllanthus niruri. AIDS Research Human Retroviruses 8:1937-1944.

PIERIK, R.L.M. 1989. In vitro culture of higher plants. Martinus Nijhoff Publishers, Dordrecht.

RAO, C.S., EGANATHAN, P., ANAND, A., BALACRISHNA, P. \& REDDY, T.P. 1998. Protocol for in vitro propagation of Excoecaria agallocha L., a medicinally important mangrove species. Plant Cell Reports 17:861-865.

SANTOS, A.R.S., CECHINEL FILHO, V., VIANA, A.M., MORENO, F.N., CAMPOS, M.M., YUNES, R.A. \& CALIXTO, J.B. 1994. Analgesic effects of callus culture extracts from selected species of Phyllanthus in mice. Journal of Pharmaceutical Pharmacology 46:755-759.

SARADHI, P.P. \& ISLAMIA, J. M. 1997. Phyllanthus fraternus - A plant with anti-hepatitis viral activity. Industrial Crop and Products 6:35-40.

SCHENK, R.U. \& HILDEBRANDT, A.C. 1972. Medium and techniques for induction and growth of monocotyledonous and dicotyledonous plant cell cultures. Canadian Journal of Botany 50:199-204.

SHEAD, A., VICKERY, K., PAJKOS, A., MEDHURST, R., FREIMAN, J., DIXON, R. \& COSSART, Y. 1992. Effects of Phyllanthus plant extracts on duck hepatitis B virus in vitro and in vivo. Antiviral Research 18:127-138.

SMITH, L.B., DOWNS, R.J. \& KLEIN, R.M. 1988. Euphorbiaceas. Flora Ilustrada Catarinense 1:1-409. 
THYAGARAJAN, S.P., SUBRAMANIAN, S., THIRUNALASUDARY, T., VENKASTEWARAN, P.S. \& BLUMBERG, B.S. 1988. Preliminary study: the effect of Phyllanthus amarus on chronic carriers of hepatitis B virus. Lancet 2:764-766.

UENO, H., HORIE, S., NISHI, Y., SHOGAWA, H., KAWASAKIM, M., SUZUKI, S., HAYASHI, T., ARISAWA, M., SHIMIZU, M., YOSHIZAKIM, M., MORITA, N., BERGANZA, L.H., FERRO, E. \& BASUALDO, I. 1988. Chemical and pharmaceutical studies on medicinal plants in Paraguay. Geraniin, an angiotensin-converting enzyme inhibitor from "papaparai mi", Phyllanthus niruri. Journal of Natural Products 51:357-359.

ULYSSEA, M. \& AMARAL, L.G. 1997. Contribuição ao estudo do gênero Phyllanthus (Euphorbiacea) ocorrente na Ilha de Santa Catarina, Brasil. Insula 26:1-28.
UNANDER, D.W. 1991. Callus induction in Phyllanthus species and inhibition of viral DNA polymerase and reverse transcriptase by callus extracts. Plant Cell Reports 10:461-466.

UNANDER, D.W. 1996. Phyllanthus species: in vitro culture and production of secondary metabolites. In Biotechnology in agriculture and forestry (Y.P.S. Bajaj, ed.), v.37 Springer-Verlag, Berlin, p.304-318.

VENKATESWARAN, P.S., UNANDER, D.W., BLUMBERG, B.S., HALBHERR, T., SHARAGER, D., DAHL, L., KRAUS, M., RISSINGER, C. \& SIMMONS, H.H. 1987. Potential antiviral agents for the treatment of hepatitis B virus and retroviruses. Scientia Reports 300-301.

WHITE, P.R. 1963. The cultivation of animal and plant cells. 2 ed. Ronald Press, New York. 